\title{
PSIKOLOGI SASTRA DALAM NOVEL BULAN TERBELAH DI LANGIT AMERIKA \\ KARYA HANUM SALSABIELA RAIS DAN RANGGA ALMAHENDRA \\ Oleh \\ Eni Marlina \\ enimarlina777@,gmail.com
}

\author{
Universitas PGRI Palembang
}

\begin{abstract}
Novel can be understood by studying from various aspects and approach one of them by using approach of Literary Psychology. Research in the Novel of the Moon Split in the sky of America by Hanum Salsabiela Rais and Rangga Almahendra is focused on Personality figures included in the type of id (Das Es), Ego (Das Ich) and Super Ego (Das Ueber Ich) according to the theory of Sigmund Freud, Based on the results of research related to the study of literary psychology in novel Moon Splitted in the Sky American by Hanum Salsabiela Rais and Rangga Almahendra can be put forward as follows (1) Story in the novel of the Moon Split in the Sky America The work of Hanum Salsabiela Rais and Rangga Almahendra is centered on the central figure, whereas the additional figure of the writer described by the author is seen as a result of the actions performed by the main mat (2) the personality of the figure based on Singmund Freud's theory in the novel of the Spherical Moon in the Sky America In accordance with the problem formulation that is (a) aspect Id (Ice Dai) which includes change facial expression to (B) Ego (Das Ich) which is the nature and feelings of the characters such as the feeling of annoyance, sadness, and sadness, Tortured, and happy, (c) Super ego (Das Ueber Ich) embodied in the form of interaction of the characters with others, remind each other in the goodness, and the internal conflict that occurs within the characters and kinflik that occur between characters with characters Others.
\end{abstract}

Keywords: Psychology, Literature, Moon novel Split in American Skies

\section{PENDAHULUAN}

Karya sastra bersifat imajinasi yaitu mampu menimbulkan citra atau bayangan-bayangan tertentu didalam benak penikmatnya. Ia mampu membangkitkan perasaan-perasaan senang, sedih, marah, benci, dendam dan sebagainya. Menurut, Mursal Esten (1978:9) Sastra atau Kesusastraan adalah pengungkapan dari fakta artistik dan imajinatif sebagai manifestasi kehidupan manusia. (dan masyarakat) melalui bahasa sebagai medium dan memiliki efek yang positif terhadap kehidupan manusia (kemanusiaan).

Sementara Muslim (2010:14) menyatakan "Karya sastra merupakan karya imajinatif. Meskipun demikian tidak jarang karya sastra itu terlahir karena pengarangnya sehingga menjadi karya sastra fakta itu dibumbui dengan imajinasi pengarangnya. Dengan demikian, fakta yang tercermin di dalamnya menjadi fakta imajinatif". Pada umumnya sastra dipahami sebagai satu bentuk kegiatan manusia yang 
tergolong karya seni yang menggunakan bahasa sebagai bahan. Jadi bahasa merupakan karakteristik sastra sebagai karya seni. Pemilihan novel Bulan Terbelah di langit Amerika Karya Hanum Salsabiela Rais dan Rangga Almahendra, dilatar belakangi oleh adanya keinginan untuk memahami aspek psikologi tokoh-tokoh..

Berdasarkan hasil pembacaan penulis sebagai peneliti dalam novel Bulan Terbelah Di Langit Amerika karya Hanum Salsabiela Rais dan Rangga Almahendra, menangkap bahwa banyak terkandung secara tersurat jenisjenis perwatakan dan kepribadian para tokoh, maka penulis dapat mengidentifikasi beberapa permasalahan yang dipertanyakan tentang kepribadian tokoh yang termasuk dalam id,ego,super ego, menurut teori Sigmund Freud.. Berdasarkan latar belakang yang dikemukakan, maka masalah dalam penelitian ini adalah bagaimanakah watak tokoh yang ada didalam novel ini, dan yang termasuk dalam jenis $i d$, ego, dan super ego menurut teori Sigmund Freud.

Menurut Endraswara (2008:86), "Sastra adalah sastra. Namun, dapat dikatakan sastra adalah ungkapan jiwa, sastra itu wakil jiwa lewat bahasa dan lewat simbol sastra itu mewadahi jiwa hingga sastra itu menarik. Psikologi dan karya sastra memiliki hubungan fungsional, yakni sama-sama berguna untuk sarana mempelajari keadaan kejiwaan orang lain. Perbedaannya hanya, gejala kejiwaan yang ada dalam karya sastra adalah gejala-gejala kejiwaan dari manusia-manusia imajiner, sedangkan dalam psikologi adalah manusia-manusia nyata". Menurut Jatman dan Roekhan (dikutip Endraswara, 2008:87), bahwa "Sastra sebagai gejala kejiwaan, didalamnya terkandung fenomena-fenomena kejiwaan yang tampak lewat perilaku tokoh-tokohnya. Sastra merupakan sebuah karya seni yang memiliki budi, imajinasi, dan emosi. Sastra lahir disebabkan dorongan dasar manusia untuk mengungkapkan dirinya, menaruh minat terhadap masalah manusia dan kemanusiaan, dan semesta. Sastra yang telah dilahirkan oleh para sastrawan diharapkan dapat memberi kepuasan estetik dan kepuasan intelek bagi khalayak pembaca. Tetapi seringkali karya sastra tidak mampu dinikmati dan dipahami sepenuhnya oleh sebagian besar anggota masyarakat. Dalam hubungan ini perlu adanya penelaah dan peneliti sastra (Semi 1993:1). Menurut Muslim (2010:14), "Karya sastra merupakan karya imajinatif. Meskipun demikian, tidak jarang karya sastra itu 
terlahir karena pengarangnya diilhami oleh fakta kehidupan yang nyata dan dalam pengolahannya menjadi karya sastra fakta itu dibumbui dengan imajinasi pengarangnya. Dengan demikian, fakta yang tercermin di dalamnya menjadi fakta imajinatif". Berdasarkan pendapat di atas dapat disimpulkan bahwa, sastra adalah karya seni kreatif yang objeknya manusia dengan segala kehidupannya yang berisi imajinasi yang baik dan ilustrasi yang indah yang berpengaruh terhadap pembinaan jiwa yang dilukiskan atau diungkapkan melalui media bahasa.

Sastra dan psikologi terlalu dekat hubungannya. Hal ini dapat diterima karena antara sastra dan psikologi memiliki hubungan lintas yang bersifat tak langsung, dan fungsional. Tidak langsung, artinya hubungan itu ada karena baik sastra maupun psikologi, kebetulan memiliki tempat berangkat yang sama, yakni kejiwaan manusia.

Pengarang dan psikolog adalah sama-sama manusia biasa. Mereka mampu menangkap keadaan kejiwaan manusia secara mendalam. Hasil penangkapan itu setelah mengalami proses pengolahan diungkapkan dalam bentuk sebuah karya. Hanya perbedaannya, sang pengarang mengemukakannya dalam bentuk karya sastra, sedangkan psikolog, sesuai dengan keahliannya, ia mengemukakannya dalam bentuk formulasi teori-teori psikologi. Dengan demikian, tidaklah mengada-ada kalau di antara keduanya dapat dilakukan penelitian lintas disiplin. Psikologi Sastra adalah analisis teks dengan mempertimbangkan relevansi dan peranan studi psikologis. Artinya, psikologi turut berperan penting dalam penganalisisan sebuah karya sastra dengan bekerja dari sudut kejiwaan karya sastra tersebut baik dari unsur pengarang, tokoh, maupun pembacanya. Dengan dipusatkannya perhatian pada tokoh-tokoh, maka akan dapat dianalisis watak tokoh dan konflik batin yang terkandung dalam karya sastra. Jadi, Secara umum dapat disimpulkan bahwa hubungan antara sastra dan psikologi sangat erat hingga melebur dan melahirkan ilmu baru yang disebut dengan "Psikologi Sastra".

Analisis Teori Psikologi Sastra yang dilanjutkan dengan Teori Psikoanalisis dan diaplikasikan dengan meminjam teori kepribadian ahli psikologi terkenal yaitu Sigmund Freud. Dengan meletakkan teori Freud sebagai dasar penganalisisan, maka pemecahan masalah akan gangguan kejiwaan tokoh dapat dijembatani secara bertahap. 
Psikoanalisis adalah cabang ilmu yang dikembangkan oleh Sigmund Freud sekitar tahun1900-an dan para pengikutnya. Dalam struktur kepribadian Freud ada tiga unsure penting, yakni id,ego dan super ego. Menurut Bartens (2003:32) istilah lain dari tiga factor tersebut dalam psikoanalisis dikenal sebagai tiga "instansi" yang menendai hidup psikis. Dari ketiga sisten atau ketiga instansi satu sama lain saling berkaitan sehingga membentuk satu kekuatan atau totalitas. Psikoanalisis berasal dari dua kata yaitu: psike (jiwa) dan analisis, psike (jiwa) adalah baik yang sadar maupun yang tidak sadar (Januarti,2009:18).

Sigmund Freud, pendiri psikoanalisis, adalah orang pertama yang berusaha merumuskan psikologi manusia. Ia memfokuskan perhatiannya kepada totalitas kepribadian manusia bukan pada bagian-bagiannya yang terpisah. Menurut Freud, prilaku manusia merupakan hasil interaksi tiga sub system dalam kepribadian manusia id, ego, dan super ego (Rahmad 2009:19).

Dengan demikian, karya sastra dapat didekati dengan menggunakan pendekatan psikologi. Berdasarkan pendapat-pendapat di atas dapat disimpulkan bahwa sastra sebagai gejala kejiwaan, didalamnya terkandung fenomena-fenomena kejiwaan yang tampak lewat perilaku tokoh-tokohnya. Kemudian sastra adalah ungkapan jiwa, Sastra itu wakil jiwa lewat bahasa dan lewat simbol sastra itu mewadahi jiwa hingga sastra itu menarik.

\section{METODOLOGI PENELITIAN}

Penelitian ini bertujuan untuk mendeskripsikan tentang kepribadian tokoh dalam novel Bulan Terbelah Di Langit Amerika karya Hanum Salsabila Rais dan Rangga Almahera berdasarkan teori Sigmund Freud, dengan cara mendeskripsikan watak tokoh berdasarkan teori Sigmund Froud yakni id,ego dan super ego

Penelitian ini merupakan penelitian yang menganalisa data berupa dokumentasi yaitu novel Bulan Terbelah Di Langit Amerika karya Hanum Salsabiela Rais dan Rangga Almahendra, sebagai objek kajiannya, maka penelitian ini tidak terikat pada tempat dan waktu. Metode yang digunakan dalam penelitian ini adalah metode deskriptif. Menurut Nawawi (dalam Ratna, 2010:56) menjelaskan metode deskriptif dapat diartikan sebagai prosedur pemecahan masalah yang diselidiki dengan menggambarkan atau melukiskan keadaan subjek atau objek penelitian (novel, drama, cerpen, puisi) pada saat sekarang berdasarkan 
fakta-fakta yang tampak atau sebagaimana adanya. Melalui metode deskriptif ini, peneliti menggambarkan dan melukiskan analisis psikologi berdasarkan teori Sigmund Frud.

Selanjutnya menurut Arikunto (2002:2113) "Metode deskriptif ialah cara penelitian yang berusaha mendeskripsikan sesuatu dan bertujuan menggambarkan keadaan dari sesuatu yang diteliti secara sistematis dan objektif'. Sistimatis yakni membaca secara keseluruhan novel dimulai dari halaman awal hingga akhir, kemudian mencatat dan mengklasifikasikan kutipan-kutipan yang terdapat dalam novel Bulan Terbelah Di Langit Amerika yang menunjukkan ciri kepribadian para tokoh yang termasuk ke dalam jenis id, ego, dan super ego, dan yang dialami tokoh sesuai dengan keaslian data yang terdapat dalam novel tersebut tanpa ada penembahan maupun pengurangan data-datan. Data diperoleh melalui studi pustaka, teknik yang dipergunakan dalam penelitian ini adalah teknik catat. Teknik catat adalah teknik yang digunakan untuk mengumpulkan data yang terdapat dalam sebuah karya sastra, lalu ditulis dalam bentuk catatan. Setelah data diperoleh, dikumpulkan, dan dicatat, selanjutnya dikelompokan, lalu dianalisis sesuai dengan masalah dan tujuan pengkajian sastra.

Selanjutnya teknik yang digunakan untuk menganalisis data dengan teknik analisis konten. "Teknik analisis konten adalah strategi untuk menangkap pesan karya sastra" (Endraswara, 2008:161). Teknik analisis konten ini digunakan untuk mengungkap, memahami, dan menangkap pesan dalam novel Bulan Terbelah Di Langit Amerika yang berupa ungkapan psikologi.

\section{HASIL PENELITIAN}

Temuan dalam penelitian ini merupakan hasil analisis yang pada dasarnya merupakan pokok-pokok temuan penelitian yang memiliki kecenderungan mengenai psikoanalisis tokoh berdasarkan teori Sigmund froud yang termasuk dalam id,ego, seper ego, hasil penelitian ini merupakan hasil jawaban dari permasalahan. Penelitian ini didasarkan pada asumsi bahwa dalam setiap karya sastra (novel, cerpen, drama, dan puisi) yang menghasilkan berbagai jenis karakterristik tokoh yang berbeda-beda. Psikoanalisis tokoh dalam Novel Bulan Terbelah di Langit Amerika Karya Hanum Salsabiela Rais dan Rangga Almahendra berdasarkan teori Sigmund Froud sebagai berikut: 


\section{Id (Das Es) Tokoh}

Id (Das Es) adalah suatu alat refleksi yang segera melepaskan diri melalui saluran-saluran motoris setiap rangsangan sensoris yang tiba padanya. Das Es adalah perubahan raut wajah secara mendadak atau perubahan ekspresi wajah terhadap suatu peristiwa dan gerakan-gerakan fisik. Id yang dialami oleh tokoh Hanum dalam novel Bulan Terbelah di Langit Amerika dapat dilihat dari kutipan-kutipan berikut ini:

\section{1). Perubahan Raut Wajah}

Perubahan raut wajah tokoh Hanum, ketika dia mendengar pernyataan bosnya tentang permintaan dewan redaksi untuk menulis artikel yang dianggapnya luar biasa, hal ini dapat dilihat dari kutipan berikut.

"Hatiku bergemuruh. Keringkonganku tersekat. Mataku sempat mendelik. Kini aku tau apa yang dimaksud Gertrud denga "emergency". Ini bukan masalah ibunya. Bukan juga masalah redaksi yang memintanya untuk membuat berita gila. Bukan pula masalah perusahaan ini akan bangkrut. Ini masalahku dengan keyakinanku. (Rais dan Almahendra, 2014:21)

Kutipan diatas menggambarkan bahwa perubahan raut wajah pada tokoh Hanum yang mendadak emosi ketika mendengar Gertrud menyampaikan keinginan dewan redaksi untuk menulis artikel perdana dalam format full service-nya dengan topic "Would the word be better without Islam" Akankan dunia lebih baik tanpa Islam?.”

Selanjutnya perubahan raut wajah pada tokoh Hanum juga, dapat terlihat pada kutiupan berikut ini.

"Hanum, aku ini mualaf. Abe, suamiku meninggal dalam tregedi itu," bisik Julia tibatiba kepadaku.

Aku terbelalak mendenganr pengakuan Jualia. Aku menoleh padanya tersadar dari keasikanku mengamati tingkah laku orang-orang di subway ini. Bukan pernyataan "mualaf" yang mengagetkannku. Tapi pernyataannya bahwa suaminya tewas dalam tragedi itu. (Rais dan Almahendra, 2014:125-126)

Deskripsi singgkat berdasarkan kutipan diatas, memperlihatkan perubahan raut wajah tokoh Hanum yang terlihat terbelalak dengan ucapan Julia Collins, yang mengatakan bahwa dia adalah seorang mualaf dan suaminya juga merupakan salah satu korban tragedy $9 / 11$. Kemudian perubahan raut wajah Tokoh Hanum dalam novel Bulan Terbelah di Langit Amerika ini juga terlihat ketika dia menyadari bahwa julia Collins adalah salah satu narasumber yang ada dalam daftar nama hasil riset milik Gertrud yang disia-siakannya. Hal tersebut dapat dilihat pada kuitipan berikut .

"Kau punya nama muslim? Pekik 
$\mathrm{ku}$ sambil merayapi wajah teduhnya.

“ Nama muslimku Amala Husein. Yang berarti cita-cita.

Kalau nama muslim ibuku

Azima Hussein," ungkap

Sarah lirih. Bagai ombak yang menggulungku, jantungku berdesir kuat mendengar nama itu. Mataku kuedarkan keseluruh wajah perempun yang ada di hadapannku sekarang ini julua Cillins." (Rais dan Almahendra, 2014:125-126)

Kutipan di atas mengambarkan bahwa perubahan raut wajah pada tokoh Hanum yang merasakan bagai ombak yang menggulunnya dan jantungnya berdesir kuat, serta matanya diedarkannya keseluruh wajah perempuan yang ada dihadapannya, saat mendengar nama muslim dari Julia Collin tersebut.

\section{2). Gerakan Fisik}

Gerakan-gerakan fisik yang terlihat pada tokoh Hanum yang merupakan perwujudan Id (Das Es) dapat terlihat pada kutipan berikut

"Aku menggeleng keras.

Kini tangan Gertrud sudah mencengkram pelan lenganku. Aku benci ini, ini senjatanya untuk menjinakkanku. Kini wajahnya sudah memelas pula. Aku menghela napas panjang kesekian kali. (Rais dan Almahendra, 2014:56)
Dari kutipan diatas dapat dilihat gerakan pisik tokoh Hanum ketika dia menggelengkan kepalanya dengan keras waktu tokoh Gertrud mencengkram pelan lengannya, selanjutnya gerakan pisik tokoh Hanum juga dapat dilihat pada kutipan berikut ini

"Perutku tiba-tiba sakit
setengah mati. Aku
meringkukkan tubuh untuk
menahan perutku yang tiba-
tiba melilit. Ini kesakitan yang
bertubi. Aku mengelap
lututku yang berdarah.
Jalanan yang berlubang tadi
telah merobek sedikit celana
panjangku dan menyayat kulit
lututku sepanjang 2
sentimeter syal yang
melingkar dileher kucopot
cepat dan kujadikan penahan
darah yang mengalir. (Rais
dan Almahendra, 2014:108)

Gerakan pisik yang terlihat pada tokoh Hanum yang mewujudkan Id (Das Es) jelas terlihat pada kutipan diatas, ketika dia sedang meringkukkan tubuhnya menahan sakit perut yang luar biasa dan mengelap lututnya yang berdarah, waktu dia menyelamatkan dirinya dalam kerusuhan pendemo dalam peringatan $8 / 11$ yang memprotes pembangunan Masjid Ground Zero.

\section{Ego (das ich) Tokoh}

Ego (Das Ich) adalah aspek psikilogis untuk berhubungan secara baik dengan dunia kenyataan (realitas). Ego (Das Ich) ini adalah fungsi control yang baik untuk memenuhi dorongan 
dasar. Ego (Das Icah) dalam diri manusia berupa rasa penyesalan, kesal, tersiksa batin, sedih, pasrah, bahagia, terpukul, dan kecewa serta rasa putus asa. Berikut Ego digambarkan pada tokoh Hanum dalam novel Bulan Terbelah di Langit Amerika melalui kutipan-kutipan berikut:

\section{1) Marah}

Perasaan marah yang merupakan bentuk Ego (Das Ich) tokoh Hanum dalam Novel Bulan Terbelah di Langit Amerika, ditunjukkan tokoh Hanum dalam kutipan berikut ini.

"Tidak Frau Robinson yang terhormat, kau suruh saja Jacob, lebih baik aku meliput festival kaum homo atau fotografer tunik gila itu, daripada artikel yang memfitnah agamaku." Jababku ketus. . (Rais dan Almahendra, 2014:47)

\section{Berdasarkan kutipan diatas} memberikan gambaran bagaimana sosok tokoh Hanum begitu marahnya kepada tokoh Gertrud yang dianggapnya telah melecehkan keyakinannya dengan menyuruhnya untuk membuat sebuah artikel yang menyudutkan keyakinannya.

Selanjutnya bentuk kemarahan tokoh Hanum dapat juga dilihat pada kutipan berikut

"Mas! Jangan melantur! Aku harus mencari nara sumber yang pasti. Yang berkarakter.
Keluarga korban 11 September. Dari sisi muslim dan nonmulsim. Bukan wawancara sama orang yang jelas-jelas tidak mau diwawancara!" (Rais dan Almahendra, 2014:69)

Kutipan diatas menggambarkan bahwa tokoh Hanum sangat marah kepada suaminya tokoh Rangga ketika dia berdua sedang mendiskusikan tentang siapa yang akan diwawancarainya untuk membuat artikel yang ditugaskan oleg bosnya Gertrut yang bertemah 'akankah dunia lebih baik tanpa Islam'

\section{2) Bahagia}

Perasaan bahagia yang menghampiri tokoh Hanum terlihat nyata ketika, t Dia berjumpa dengan tokoh Rangga Suaminya. Hal tersebut dapat dilihat dari kutipan berikut

"Aku memeluk Rangga
seerat-eratnya saat dia
membalikkan badan. Ada
kekuatan yang berlebihan
darinya ketika melepas
cengkraman tanganku.
Reaksinya seperti sedang
melayani lawan tangguh.
Aku tekekeh dalam hati.
Satu detik itu kami saling
pandang. Dan aku sudah tak
sadar kapan dia benar-benar
memelukku. Ya, inilah reuni
kerinduan tak terperih dari
syami-istri yang baru saja
dipisahkan "Terelakkan!"
(Rais dan Almahendra,
2014:250)


Rasa bahagia tokoh Hanum terlihat ketika dia dipeluk erat oleh suaminya, mereka saling pandang, dan meluapkan rasa rindu yang tak terperih setelah perpisahan keduanya selama dua hari din kota Washington DC itu. Rasa bahagia tokoh Hanum ini merupakan salah satu pencerinan sikap Ego (Das Ich) yang dimiliki oleh tokoh Hanum.

Perasaan bahagi tokoh Hanum juga terlihat ketika dia mendapatkan kejutan dari suaminya yang mendapatkan 5 brode ticket untuk masuk ke arena dalam liputan eksklusif dengan filantropi dunia dalam acara CNN TV Heroes secara live. Hal tersebut dapat kita lihat pada kutipan berikut.

"Oh ya, Brown menitipkan 5 barcode ticket untuk masuk ke arena. Dia bersedia menerima wawancara eksklusif denganku untuk paper keduaku. Dan tentu saja, ajakan Reinhardpun diterima. Kurasa kalaupun kamu mau mewawancarainya, dia pun bersedia. Dia punya cerita yang bagus untuk artikelmu.

"Hebaaaaat? Mas

Rangga Hebat!

Kok bisa sih,

Mas?" (Rais dan

Almahendra,

2014:250)

Kebahagiaan tokoh Hanum terlihat ketika tokoh Rangga suaminya menunjukkan 5 tiket untuk menonton langsung wawancara ekslusif pada acara
CNN TV Heroes secara live dan kerika tokoh Rangga juga mengatrakan bahwa di juga bisa mewawancarai tokoh Phillipus Brown seorang filantropi dari Amerika itu. Rasa bahagia ini merupak salah satu pencerminan sikap Ego (Das Ich) yang dimiliki oleh tokoh Hanum

\section{3) Kagum}

Perasaan kesal adalah salah satu yang dialami oleh tokoh Hanum, yang merupakan salah satu perwujudan Ego (Das Ich) yang dimiliki oleh tokoh Hanum dapat dilihat dari kutipan berikut ini

"Begitu mencengangkan bagaimana negeri raksasa seperti Amerika dengan kemnampuannya melakukan taksidermi pengawetan hewan dengan jalan dikeringkan-mampu menghadirkan mamalia ikon Negara-negara dunia secara lengkap koleksinya bahkan lebih lengkap daripada Naturisches Historiche Museum di Wina, yang kabarnya juga memiliki awetan orangutan asli Indonesia! (Rais dan Almahendra, 2014:269)

Berdasarkan kutipan diatas, perasaan kagum tokoh Hanum terlihat ketika dia tercengang melihat bagaimana negeri raksasa Amerika mampu melakukan taksidermi pengaweran hewan dengan jalan dikeringkan hingga mampu secara lengkap menghadirkan mamalia ikon nedara-negara dunia. 


\section{Super Ego (Das Uber Ich) Tokoh}

Super Ego (Das Ueber Ich)

merupakan aspek sosiologi kepribadian yang merupakan nilai-nilai serta cita-cita masyarakat sebagaimana ditapsirkan sebagai perintah dan larangan serta keadaan manusia dengan lingkungannya. Di dalam novel Bulan Terbelah di Langit Amerika karya Hanum Salsabiela Rais dan Rangga Alamhendra. Super Ego (Das Ueber Ich) yang terdapat pada tokoh Hanum ceritanya tergambar dalam kutipankutipan berikut ini:

Dalam novel Bulan Terbelah di Langit Amerika, ini bentuk kepribadian tokoh Hanum yang mencerminkan Super Ego (Das Ueber Ich) dapat kita lihat dari kutipan berikut ini

"Gertrud, aku terima
tantanganmu. Aku akan
menulis artikel itu."
"Terima kasih, Hanum. Aku
bersyukur. Kau tahu, jika
Jacob yang menulisnya,
pernyataan itu jelas akan
terjawan 'ya'. Denganmu
seorang muslim, aku berharap
kau menjawab pernyataan itu
dengan 'tidak'. Kau paham
kan sekarang?" (Rais dan
Almahendra, 2014:51)

Berdasarkan kutipan diatas, bentuk interaksi yang mewujudkan Super Ego (Das Ueber Ich) pada tokoh Hanum ketika dia sedang berbincang dengan bosnya Gertrud Robinson, terlihat sebagai perintah dan larangan serta keadaan manusia dengan lingkungannya, pada saat hanum menerima tawaran bosnya untuk menulis artikel yang dianggapnya akan menaikkan opla dan menjadi berita yang luar biasa.

\section{SIMPULAN}

Berdasarkan hasil penelitian dan pembahasan dapat disimpulkan bahwa dalam novel Bulan Terbelah di Langit Amerika karya Hanum Salsabiela Rais dan Rangga Almahendra, terdapat kepribadian tokoh yang didasari teori Sigmund Freud yang sesuai dengan aspek Id (Das Ich), Ego (Das Es), Super Ego (Das Ueber Ich). Ketiga jenis kepribadian tersebut tercermin dari prilaku dan tindakan yang dilakukan oleh para tokohnya antara lain, tokoh Hanum, Rangga, Julia Collins (Azima), Michael Jones, Phillipus brownd dan tokoh-tokoh lainnyayang terwujud dalam perubahan raut wajah dan gerakan-gerakan fisik yang dilakukan oleh masing-masing tokoh.

Perubahan raut wajah yang dialami oleh tokoh-tokoh yaitu perubahan raut wajah secara mendadak karena menerima reaksi-reaksi spontan seperti, marah, terkejud, merasa tersinggung terhadap ucapan, tingkah laku atau sikap. Gerakan fisik yang 
dialami tokoh dalam novel Bulan Terbelah di langit Amerika merupakan gerakan-gerakan fisik yang tejadi pada tokoh-tokoh yaitu gerakan badan, memegang, dan memukul. Ego (Das Ich) pada tokoh-tokoh dalam novel Bulan Terbelah di Langit Amerika karya Hanum Salsabiela Rais dan Rangga Almahendra yaitu sedih, marah, tersiksa batin, bahagia dan putus asa. Adapun Super Ego (Das Ueber Ich) padsa tokohtokoh dalam novel bulan Terbelah di Langit Amerika karya Hanum Salsabiela Rais dan Rangga Almahendra yaitu berinteraksi dengan dengan orang lain, saling mengingatkan dan saling membantu, simpti terhadap kesusahan orang lain dan saling mengingatkan dalam kebaikan.

\section{DAFTAR PUSTAKA}

Arikunto, Suharsimi. 2010. Prosedur Penelitian Suatu Pendekatan Praktik. Jakarta: PT Asdi Mahasatya

Endraswara, Suwardi. 2008. Metode Penelitian Psikologi Sastra. Yogyakarta: Media Pressindo.

Endraswara, Suwardi. 2011. Metodologi Penelitian Sastra. Yogyakarta: CAPS.

Endraswara, Suwardi. 2013. Metode Penelitian Sastra. Yogyakarta: Media Presindo.

Muslim. 2010. Menulis Karya Sastra. Palembang. CV Yoda Sahuri.
Suryabtara, Sumardi 2014, Psikologi Pendidikan Jakarta: PT Rajagrafindo

Semi, M. Atar. 1993. Metode Penelitian Sastra. Bandung: Angkasa

Ratna, Nyoman Kutha. 2011. Teori, Metode, dan Teknik Penelitian Sastra. Yogyakarta: Pustaka Pelajar. 
